\title{
Internal bra: a unifying solution for reconstructive and aesthetic breast surgery issues
}

\section{Richard A. Baxter}

Baxter Plastic Surgery PLLC, Mountlake Terrace, WA 98043, USA.

Address for correspondence: Dr. Richard A. Baxter, Baxter Plastic Surgery PLLC, 6100 219th St SW, Suite 290, Mountlake Terrace, WA 98043, USA. E-mail: drbaxter@drbaxter.com.

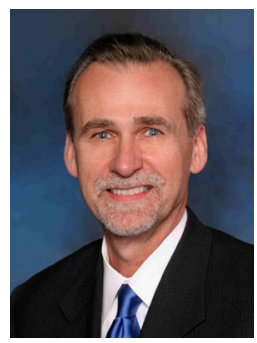

Dr. Richard A. Baxter has a special interest in revision breast surgery, internal bra concepts, and ultrasound in aesthetic medicine. In addition to his busy private plastic surgery practice in the Seattle area, he is engaged in clinical research, figure drawing, and learning Argentine tango.

\begin{abstract}
The utility of the internal bra for breast support, reconstruction, and in revision breast surgery has been recognized and various materials have been introduced for this application. As clinical experience has grown and new products have been developed, the roles of these materials are becoming better defined. This paper reviews the use of the internal bra concept to date.
\end{abstract}

Key words:

Internal bra; acellular dermal matrix; alloderm; strattice; SERI surgical scaffold; GalaFLEX mesh; revision breast surgery; mastopexy

\section{INTRODUCTION}

Factors leading to revision breast implant surgery include capsular contracture, implant malposition, palpability, and animation deformity with subpectoral placement. These issues often occur in combination, ${ }^{[1]}$ for example lower or lateral fold malposition with rippling or animation deformity with fold malposition. Reoperation rates for breast implant procedures are high, and even higher for previous revision surgery. ${ }^{[2]}$ A comprehensive approach is needed if these numbers are to be improved.

There are certain commonalities underlying the issues

\begin{tabular}{|l|l|}
\hline \multicolumn{2}{|c|}{ Access this article online } \\
\hline Quick Response Code: & Website: \\
\hline & www.parjournal.net \\
\cline { 2 - 3 } & DOI: \\
\hline
\end{tabular}

leading to revision breast surgery. Implant malposition and rippling are manifestations of thin tissue coverage, which can be thought of as periprosthetic atrophy. This in turn may relate to overly large implants, improper biodimensional planning, and saline implants as a result of fluid wave action. Aging, pregnancies, weight loss, and prior surgeries may contribute to weakening of the ligamentous support and soft tissue envelope of the breast. In combination, these patient-related and implant-related factors may multiply the severity of periporsthetic atrophy. Autologous material such as capsule flaps ${ }^{[3,4]}$ and fat grafting can be useful adjuncts in

This is an open access article distributed under the terms of the Creative Commons Attribution-NonCommercial-ShareAlike 3.0 License, which allows others to remix, tweak and build upon the work non-commercially, as long as the author is credited and the new creations are licensed under the identical terms.

\section{For reprints contact: service@oaepublish.com}

How to cite this article: Baxter RA. Internal bra: a unifying solution for reconstructive and aesthetic breast surgery issues. Plast Aesthet Res 2016;3:3-7.

Received: 15-06-2015; Accepted: 12-01-2016 
Table 1. Criteria for the ideal internal bra material

\begin{tabular}{l}
\hline Criteria \\
\hline No interference with mammography \\
Biocompatible \\
Bio-inductive: template for long-term host tissue replacement \\
Maintains strength until host tissue replacement \\
Handling characteristics: easy to template and suture \\
Easily stored and ready-to-use \\
Available in a range of sizes \\
Affordable \\
Natural feel
\end{tabular}

recreating a stable breast implant pocket, but are not always capable of providing a comprehensive solution.

Recognition of the potential benefit of non-autologous internal breast support was initially constrained by the lack of suitable materials [Table 1]. Most of the products were developed for hernia repair and general soft tissue support rather than for breast procedures specifically. These materials can be classified as first generation (nonresorbable synthetics), second generation (acellular dermal matrix), and third generation (slowly resorbable textiles) [Table 2]. The developing role of these products will be reviewed.

\section{FIRST GENERATION INTERNAL BRA MATERIALS}

The use of polypropylene mesh with reduction mammoplasty was reported in $1981,,^{[5]}$ and more recently a threedimensional pre-shaped polyester mesh was developed. ${ }^{[6]}$ Because Wise pattern/inverted $T$ patterns rely on the skin envelope to shape the breasts, by offloading the support and shaping of the breast from the skin to the mesh, the role of short scar techniques expanded. Góes ${ }^{[7]}$ originally proposed the use of resorbable mesh with periareolar mastopexy but noted longer lasting results with a mixed mesh $(40 \%$ polyester, $60 \%$ polyglactin). More recently, a titanium-coated mesh $\left(\right.$ TiLOOP $^{\circledR}$ Bra) has been introduced in Europe. ${ }^{[8]}$ Nevertheless, concerns about biofilms and a permanent foreign body in the subcutaneous layer of the breast have limited the adoption of this approach. ${ }^{[9]}$ For these same reasons, non-resorbable meshes have had limited use in revision breast surgery although they helped establish proof of concept for the idea of an internal bra.

\section{SECOND GENERATION MATERIALS}

Duncan ${ }^{[10]}$ first reported the use of human-derived acellular dermal matrix (ADM) in revision breast surgery for correction of implant rippling. This was later expanded to include a variety of implant-related problems, with the common denominator being inadequate soft tissue support and/or coverage. ${ }^{[1]}$ Histologic analysis demonstrated integration and transformation into host tissue, with follow-up as long as 12 years. $^{[12]}$ The ability of these materials to replace deficient or weakened tissue led to their widespread adoption in breast reconstruction and revision breast surgery and became the standard for many years. ${ }^{[13 \mid}$ Host tissue response and long-term integration may be affected by decellularization and sterilization methods which can alter the architecture of the matrix. ${ }^{[14]}$

ADM's have proven valuable in the setting of revision breast implant surgery, for both reconstructive and cosmetic cases. ${ }^{[15-17]}$ In primary reconstruction, they may allow for more rapid tissue expansion and higher initial fill volumes, though prospective studies on this are limited and inconsistent. Selection of an adequately sized piece is important. ${ }^{[18]}$ Direct-to-implant immediate reconstruction with skin-sparing mastectomy relies on the use of ADM's to offload the weight of the implant from the skin envelope and control pocket shape. ${ }^{[19]}$

Further experience with ADM's revealed their resistance to radiation, of particular benefit to reconstruction patients. ${ }^{[20]}$ Another observation was a much lower than expected incidence of capsular contracture in reconstruction patients, ${ }^{[21]}$ leading to the use of ADM's in revision breast surgery for established capsular contracture. ${ }^{[22,23]}$ In this application, the material may afford protection against recurrent contracture, possibly related to altered inflammatory aspects of capsule formation. ${ }^{[24]}$ Importantly, ADM's serve to replace tissue support and implant coverage after capsulectomy. This ability to provide instant, predictable, and durable tissue thickness remains a primary advantage of ADM's. Porcine-derived ADM's, designed to offer a non-human source alternative, have found utility in this application. In general, porcine ADM's have more consistent thickness and less stretch than human-derived ADM's.

The use of ADM's has been mostly limited to the periprosthetic layer for creation of a stable pocket for implants, as a pectoral extension for post-mastectomy breast reconstruction and in revision aesthetic breast implant surgery. Use of an ADM internal bra in reduction

Table 2. Internal bra materials

\begin{tabular}{lll}
\hline First generation & Second generation & Third generation \\
\hline Mixed mesh (polyester/polyglactin) & Human ADM & Silk fibroin mesh \\
Polypropylene mesh & - Alloderm & - SERI Scaffold \\
Polyester three-dimensional cone & - Dermamatrix & P4HB mesh \\
Titanium-coated polypropylene (TiLOOP & - FlexHD & - GalaFLEX \\
Bra) & -AlloMax & - Phasix \\
& Porcine ADM & Mixed \\
& - Strattice & - TIGR (Fast resorbing copolymer of lactide, $^{\circledR}$ \\
& - Permacol & glycolide and trimethylene carbonate; \\
& & slow-resorbing copolymer of lactide and \\
& & trimethylene carbonate
\end{tabular}




\begin{tabular}{|c|c|c|}
\hline & Advantages & Disadvantages \\
\hline \multicolumn{3}{|l|}{ First generation } \\
\hline $\begin{array}{l}\text { Polypropylene mesh; } \\
\text { Mixed mesh }\end{array}$ & $\begin{array}{l}\text { Durable; } \\
\text { Affordable; } \\
\text { Variety of sizes and shapes }\end{array}$ & $\begin{array}{l}\text { Foreign body may be subject to biofilms } \\
\text { infection/exposure; } \\
\text { Possible interference with mammogram }\end{array}$ \\
\hline \multicolumn{3}{|l|}{ Second generation } \\
\hline Human-derived ADM & $\begin{array}{l}\text { Potentially very long lasting; } \\
\text { Elastic (facilitates tissue expansion); } \\
\text { Extensive clinical record }\end{array}$ & $\begin{array}{l}\text { Expensive; } \\
\text { Potential for seromas; } \\
\text { Need for long-term drains; } \\
\text { Red breast syndrome; } \\
\text { Limited sizes }\end{array}$ \\
\hline Porcine-derived ADM & $\begin{array}{l}\text { Potentially very long lasting; } \\
\text { Inelastic; } \\
\text { 1:1 correction for revision surgery; } \\
\text { Instant thickness }\end{array}$ & Same as human-derived \\
\hline \multicolumn{3}{|l|}{ Third generation } \\
\hline SERI Scaffold, P4HB mesh & $\begin{array}{l}\text { More affordable than ADM's; } \\
\text { Variety of shapes and sizes; } \\
\text { Slowly resorbing with induction of replacement } \\
\text { by host tissue; } \\
\text { Open weave may facilitate fluid egress and } \\
\text { mesh integration }\end{array}$ & Limited clinical data for breast surgery \\
\hline
\end{tabular}

ADM: acellular dermal matrix

mammoplasty has been proposed, ${ }^{[25]}$ but the large pieces required can make it expensive. In the case of reconstruction, the concept of an internal bra is logical as the breast mound is entirely comprised of the implant; in the case of a breast augmentation, the concept is more limited because it supports the implant but not breast tissue unless placed in a more superficial layer. This would require placement in a subcutaneous layer, encompassing both implant and breast. ADM's are not generally suitable for this application without extensive meshing as with skin grafts.

Disadvantages of ADM's include cost, ${ }^{[26]}$ concerns about animal or cadaveric sourcing, the need for long-term suction drains, ${ }^{[27]}$ and complications such as red breast syndrome and seromas. ${ }^{[28,29]}$ Placement of fenestrations may ameliorate these issues to a degree. ${ }^{[30]}$ Another limitation is the inability to form an adherent capsule on textured implants, which may be desired in some cases to prevent rotation of formstable implants.

\section{THIRD GENERATION}

As ADM's helped to propel the concept of an internal bra, the need for more versatile materials became evident. Slowly resorbing materials which induce formation of a strong and durable host tissue layer would have the versatility of permanent meshes and the biocompatiblility of ADM's. SERI ${ }^{\circledR}$ surgical scaffold (Allergan, Inc.), comprised of purified fibroin silk, and meshes based on poly-4-hydroxybutyrate (GalaFLEX ${ }^{\circledast}$, Tepha Medical Devices) are the leading products in this category.

Silk-based scaffolds have been explored in various reconstructive surgery applications because of their potential to induce a host response characterized by sitespecific tissue replacement. ${ }^{[31]}$ Raw silk consists primarily of two proteins: fibroin, comprised of fibers with high tensile strength, and sericin, a glue-like substance which coats the fibroin strands but provokes an inflammatory response as an implant. Removal of the sericin component yields a biocompatible material that can be woven or knitted into various configurations. ${ }^{[32]}$ Experimentally, implantation is quickly followed by fibroblast migration, adherence, and proliferation. ${ }^{[33]}$ Early iterations of implantable fibroinbased scaffolds included anterior cruciate ligament ${ }^{[34]}$ and abdominal wall repair. ${ }^{[35]}$ Silk scaffolds seeded with specific cell lines or growth factors is an active area of research in tissue engineering. ${ }^{[36]}$

SERI ${ }^{\circledR}$ surgical scaffold is a knitted multifilament implantable material derived from the cocoons of the silkworm Bombyx mori. It is easily cut without unraveling and suitable for a variety of applications in breast reconstruction, revision breast surgery, and some cases primary aesthetic breast surgery such as augmentation-mastopexy. ${ }^{[37]}$ In an ovine model of two-stage breast reconstruction, SERI scaffold demonstrated maintenance of burst strength greater than host fascia through 12 months, with histologic evidence of scaffold resorption and replacement by new tissue. ${ }^{[38]}$ Interim one-year data from an ongoing clinical trial of twostage breast reconstruction shows low complication rates and high patient satisfaction. ${ }^{[39]}$ Early results from a European trial with SERI in direct-to-implant reconstruction after skinsparing mastectomy showed good aesthetic outcomes and acceptable complication profile. ${ }^{\mid 40]}$

Poly-4-hydroxybutyrate is a bio-derived polymer produced by micro-organisms under specific conditions. $\mathrm{P} 4 \mathrm{HB}$ is a monofilament used as a suture or knitted into a mesh, and is somewhat stiffer than SERI ${ }^{\circledR}$ scaffold. Clinical experience with P4HB meshes is extensive but only recently has it been applied to breast surgery. ${ }^{[41]}$ In a porcine model of abdominal 
wall repair, PHASIX ${ }^{\circledR}$ knitted mesh (Tepha) demonstrated burst strength significantly greater than native tissue at all points up to one year. ${ }^{[42]}$ As with silk scaffolds, a variety of uses for constructs based on PHB have been explored, including heart valves. ${ }^{[43]}$ Clinical trial results for GalaFLEX ${ }^{\circledR}$ (P4HB mesh) in breast surgery have not yet been reported but a trial in mastopexy and reduction mammoplasty is ongoing.

A composite mesh comprised of fast-absorbing and slowabsorbing fibers has also been explored $\left(\mathrm{TIGR}^{\circledR}\right.$ Matrix surgical mesh, Novus Scientific.) At an average follow-up of 16 months, a favorable complication rate was observed in a case series of breast reconstruction, revision implant surgery, and primary aesthetic procedures. ${ }^{[44]}$

Because third generation meshes facilitate subcutaneous placement, mastopexy may be performed without parenchymal disruption or reliance on a tight skin envelope. For all internal bra materials, the ability to offload the weight of the breast during the transition from graft to host is critical. Quickly-resorbing materials lose support before host tissue can develop, so the ability of the material to induce or support ingrowth or replacement by host issue is an important variable. In practice, it is important to take advantage of the internal bra concept by adapting the skin envelope of the breast to the shape created by the material and close incisions under minimal tension. This may minimize the potential for would breakdown and exposure of the material. Minimal tension closure may reduce the potential for hypertrophic scarring as well. The ability to shape the breast mound as a composite unit of implant and parenchyma by wrapping in a subcutaneous internal bra may prevent long-term problems of differential implant or breast ptosis.

\section{DISCUSSION}

By restoring support due to attenuated or weak tissues, revision surgery for combination problems may find a unifying solution with the internal bra. Despite the paucity of robust long-term data for newer materials, they are finding a role in clinical practice. Each has its own limitations and advantages [Table 3]. Although there are general characteristics that are desirable across the category, different applications require specific mesh attributes. In revision surgery, elasticity and expandability may be disadvantages while they are plusses for tissue expansion. Placement in the subcutaneous layer is necessary for mastopexy, but placement too superficially may result in unacceptable palpability or risk of exposure, while in a deeper layer, non-take may be a concern because of less vascularity. The consequences of non-take for second and third generation materials include exposure, infection, and possible need for removal of both the material and implant. As application-specific characteristics such as pore size, fiber size, monofilament vs. multifilament, degradation profiles, and textile engineering become better understood, these materials will be better optimized. The introduction of fixation devices and 3-dimensionally shaped constructs may broaden the appeal of the internal bra.

\section{CONCLUSION}

The concept of an implantable internal bra continues to evolve. Third generation biomaterials designed to act as templates that resorb and initiate tissue neogenesis address many of the issues posed by non-resorbable materials and acellular matrices, but have only recently become widely available and less is known about complication rates and best practices. As indications become better defined and clinical experience grows, the use of these materials appears poised to usher in a new generation of regenerative surgery.

\section{Financial support and sponsorship} Nil.

\section{Conflicts of interest}

There are no conflicts of interest.

\section{REFERENCES}

I. Grewal NS, Fisher J. Why do patients seek revisionary breast surgery? Aesthet Surg J 2013;33:237-44

2. Forster NA, Künzi W, Giovanoli P. The reoperation cascade after breast augmentation with implants: what the patient needs to know. J Plast Reconstr Aesthet Surg 2013;66:313-22.

3. Wessels L, Murphy S, Merten S. The capsular hammock flap for correction of breast implant ptosis. Aesthetic Plast Surg 2014;38:354-7.

4. Bogdanov-Berezovsky A, Silberstein E, Shoham Y, Krieger Y. Capsular flap: new applications. Aesthetic Plast Surg 2013;37:395-7.

5. Johnson GW. Central core reduction mammoplasties and Marlex suspension of breast tissue. Aesthetic Plast Surg 1981;5:77-84.

6. de Bruijn HP, Johannes S. Mastopexy with 3D preshaped mesh for longterm results: development of the internal bra system. Aesthetic Plast Surg 2008;32:757-65.

7. Góes JC. Periareolar mastopexy: double skin technique with mesh support. Aesthet Surg J 2003;23:129-35.

8. Dieterich M, Stubert J, Gerber B, Reimer T, Richter DU. Biocompatibility, cell growth and clinical relevance of synthetic meshes and biological matrixes for internal support in implant-based breast reconstruction. Arch Gynecol Obstet 2015;291:1371-9.

9. Dixon JM, Arnott I, Schaverien M.J Chronic abscess formation following mesh mastopexy: case report. Plast Reconstr Aesthet Surg 2010;63:1220-2.

10. Duncan DI. Correction of implant rippling using allograft dermis. Aesthet Surg J 200I;2I:8I-4.

I I. Baxter RA. Intracapsular allogenic dermal grafts for breast implant-related problems. Plast Reconstr Surg 2003; I 12:1692-6.

12. Baxter RA. Long-term follow-up with AlloDerm in breast reconstruction Plast Reconstr Surg Glob Open 2013; I:I-2.

13. Baxter RA.Acellular dermal matrices in breast implant surgery: defining the problem and proof of concept. Clin Plast Surg 20I2;39:103-I2.

14. Boone MA, Draye JP, Verween G, Aiti A, Pirnay JP, Verbeken G, De Vos D, Rose T, Jennes S, Jemec GB, Del Marmol V. Recellularizing of human acellular dermal matrices imaged by high-definition optical coherence tomography. Exp Dermatol 2015;24:349-54.

15. Spear SL, Sher SR, Al-Attar A, Pittman T. Applications of acellular dermal matrix in revision breast reconstruction surgery. Plast Reconstr Surg 2014; I33:I-10

16. Pozner JN, White JB, Newman MI. Use of porcine acellular dermal matrix in revisionary cosmetic breast augmentation. Aesthet Surg J 20I3;33:68I-90.

17. Maxwell GP, Gabriel A. Efficacy of acellular dermal matrices in revisionary aesthetic breast surgery: a 6-year experience. Aesthet Surg J 2013;33:389-99.

18. Cayci C, Santner F, Jacobson SR. Impact and outcome of human acellular dermal matrix size for immediate and two-stage breast reconstruction. Plast Reconstr Surg 2013;132:1 I-8.

19. Salzberg CA. Focus on technique: one-stage implant-based breast reconstruction. Plast Reconstr Surg 2012;130:S95-103.

20. Topol BM. The use of human acellular dermal matrices in irradiated breast reconstruction. Clin Plast Surg 2012;39:149-58.

21. Salzberg CA, Ashikari AY, Koch RM, Chabner-Thompson E. An 8-year experience of direct-to-implant immediate breast reconstruction using 
human acellular dermal matrix (AlloDerm). Plast Reconstr Surg 20 I ; 127:5 I 424.

22. Namnoum JD, Moyer HR. The role of acellular dermal matrix in the treatment of capsular contracture. Clin Plast Surg 20I2;39:127-36.

23. Hester TR Jr, Ghazi BH, Moyer HR, Nahai FR, Wilton M, Stokes L. Use of dermal matrix to prevent capsular contracture in aesthetic breast surgery. Plast Reconstr Surg 2012;130:SI26-36.

24. Leong M, Basu CB, Hicks MJ. Further evidence that human acellular dermal matrix decreases inflammatory markers of capsule formation in implantbased breast reconstruction. Aesthet Surg J 2015;35:40-7.

25. Brown RH, lzaddoost S, Bullocks JM. Preventing the "bottoming out" and "star-gazing" phenomena in inferior pedicle breast reduction with an acellular dermal matrix internal brassiere. Aesthetic Plast Surg 2010;34:760-7.

26. Hartzell TL, Taghinia AH, Chang J, Lin SJ, Slavin SA. The use of human acellular dermal matrix for the correction of secondary deformities after breast augmentation: results and costs. Plast Reconstr Surg 2010;126:1711-20.

27. Israeli Ben-Noon H, Farber N, Weissman O, Tessone A, Stavrou D, Shabtai M, Maor Y, Haik J, Winkler E. The effect of acellular dermal matrix on drain secretions after immediate prosthetic breast reconstruction. J Plast Surg Hand Surg 2013;47:308-12.

28. Israeli R. Complications of acellular dermal matrices in breast surgery. Plast Reconstr Surg 20I2; I30:SI59-72.

29. Michelotti BF, Brooke S, Mesa J, Wilson MZ, Moyer K, Mackay DR, Neves RI, Potochny J. Analysis of clinically significant seroma formation in breast reconstruction using acellular dermal grafts. Ann Plast Surg 20I3;7I:274-7.

30. Martin JB, Moore R, Paydar KZ, Wirth GA. Use of fenestrations in acellular dermal allograft in two-stage tissue expander/implant breast reconstruction. Plast Reconstr Surg 2014;134:90I-4.

31. Kundu B, Rajkhowa R, Kundu SC,Wang X. Silk fibroin biomaterials for tissue regenerations. Adv Drug Deliv Rev 2013;65:457-70.

32. Wang Y, Rudym DD, Walsh A, Abrahamsen L, Kim HJ, Kim HS, Kirker-Head C, Kaplan DL. In vivo degradation of three-dimensional silk fibroin scaffolds. Biomaterials 2008;29:34I5-28.

33. Acharya C, Ghosh SK, Kundu SC. Silk fibroin protein from mulberry and non-mulberry silkworms: cytotoxicity, biocompatibility and kinetics of L929 murine fibroblast adhesion.J Mater Sci Mater Med 2008; 19:2827-36.
34. Horan RL, Toponarski I, Boepple HE, Weitzel PP, Richmond JC, Altman GH Design and characterization of a scaffold for anterior cruciate ligament engineering.J Knee Surg 2009;22:82-92.

35. Clemens MW, Downey S, Agullo F, Lehfeldt MR, Kind GM, Palladino H, Marshall D, Jewell ML, Mathur AB, Bengtson BP. Clinical application of a silk fibroin protein biologic scaffold for abdominal wall fascial reinforcement. Plast Reconstr Surg Glob Open 20I4;2:e246.

36. Kundu B, Rajkhowa R, Kundu SC,Wang X. Silk fibroin biomaterials for tissue regenerations. Adv Drug Deliv Rev 2013;65:457-70.

37. Bengtson B, Baxter RA, Clemens MW, Bates D. A I2-month survey of early use and surgeon satisfaction with a new highly purified silk matrix: SERI surgical scaffold. Plast Reconstr Surg Glob Open 2014 7;2:el 82.

38. Gross JE, Horan RL, Gaylord M, Olsen RE, McGill LD, García-López JM, Biber K, Barnico K, Toponarski I, Altman G. An evaluation of SERI surgical scaffold for soft-tissue support and repair in an ovine model of two-stage breast reconstruction. Plast Reconstr Surg 2014;134:e700-4.

39. Fine NA, Lehfeldt M, Gross JE, Downey S, Kind GM, Duda G, Kulber D, Horan R, Ippolito J, Jewell M. SERI surgical scaffold, prospective clinical trial of a silk-derived biological scaffold in two-stage breast reconstruction: I-year data. Plast Reconstr Surg 20 15;135:339-5।.

40. De Vita R, Buccheri EM, Pozzi M, Zoccali G. Direct to implant breast reconstruction by using SERI, preliminary report. J Exp Clin Cancer Res 20I4;33:78.

4I. Williams SF, Rizk S, Martin DP. Poly-4-hydroxybutyrate (P4HB): a new generation of resorbable medical devices for tissue repair and regeneration. Biomed Tech (Berl) 20I3;58:439-52.

42. Deeken CR, Matthews BD. Characterization of the mechanical strength, resorption properties, and histologic characteristics of a fully absorbable material (poly-4-hydroxybutyrate-PHASIX Mesh) in a porcine model of hernia repair. ISRN Surg 20I3;20I3:238067.

43. Wu Q, Wang Y, Chen GQ. Medical application of microbial biopolyesters polyhydroxyalkanoates. Artif Cells Blood Substit Immobil Biotechnol 2009;37:I12.

44. Becker $\mathrm{H}$, Lind JG 2 nd. The use of synthetic mesh in reconstructive, revision, and cosmetic breast surgery. Aesthetic Plast Surg 2013;37:914-21. 